\title{
A study on the non-infectious complications of continuous ambulatory peritoneal dialysis
}

\author{
Niveditha S. ${ }^{1 *}$, Aravind S. $^{2}$, Singh L. ${ }^{3}$ \\ DOI: https://doi.org/10.17511/ijmrr.2019.i03.05 \\ 1* Niveditha S., Assistant Professor, Department of Medicine, Sri Devaraj Urs Medical College, Kolar, Karnataka, India. \\ 2 Aravind S., Postgraduate Student, Department of Medicine, Regional Institute of Medical Science, Imphal, Manipur, India. \\ 3 L.K. Sharatchandra Singh, Professor, Department of Medicine, Regional Institute of Medical Science, Imphal, Manipur, India.
}

Introduction: Patients with end-stage renal disease (ESRD) are treated with hemodialysis (HD) or continuous ambulatory peritoneal dialysis (CAPD). Non-infectious complications of CAPD are increasing in relative importance due to success in decreasing the rate of peritonitis. Aims and Objectives: Our aim was to study the non-infectious complications in patients of ESRD on CAPD and to study the impact of the non-infectious complications in the survival of CAPD catheters. Materials and Methods: A prospective study has been conducted at Regional institute of medical science, Imphal in a total of 71patients of ESRD who are already on CAPD or newly diagnosed ESRD who have undergone CAPD catheter implantation. Their detailed history, clinical examination and relevant laboratory investigations were done and the different non-infectious complications were identified and analysed. Result: Out of the 71 patients studied 39 patients had complications like hypokalemia (15 patients), omental wrap (10 patients), catheter tip migration (6 patients), haemoperitonium (2 patients), hydrothorax (2patients), exit site leak (2patients), abdominal wall edema (1patient), catheter block(1patient). Conclusion: In our study the most common noninfectious complication was hypokalemia followed by omental wrap and catheter tip migration. Knowledge about the common prevalent non-infectious complications of CAPD alerts the treating doctor to take up the specific corrective steps at an earlier stage, thus preventing the morbidity associated with the same. We conclude that the majority of non-infectious complications in these patients were treatable and did not interfere with the catheter survival.

Keywords: CAPD, ESRD, Non-infectious complications, Omental wrap, Catheter tip migration

Corresponding Author

Niveditha S., Assistant Professor, Department of Medicine, Sri Devaraj Urs Medical College, Kolar, Karnataka, India

Email: nivedita0212@gmail.com

\section{How to Cite this Article}

Niveditha S, Aravind S, Singh LKS. A study on the non-infectious complications of continuous ambulatory peritoneal dialysis. Int J Med Res Rev. 2019;7(3):176-181.

Available From

https://ijmrr.medresearch.in/index.php/ijmrr/article/ view/1055
To Browse

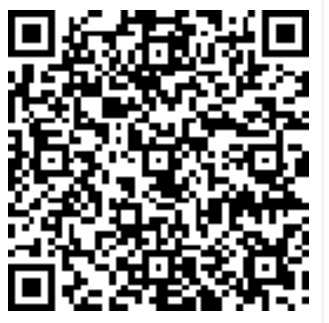

Manuscript Received 2019-05-18

Conflict of Interest No
Review Round 1 2019-05-28

Funding $\mathrm{Nil}$

Review Round 2
2019-06-04
Ethical Approval
Yes

Review Round 3

Accepted 2019-06-08

Plagiarism $X$-checker $9 \%$

Note

(c) 2019 by Niveditha S., Aravind S., L.K. Sharatchandra Singh and Published by Siddharth Health Research and Social Welfare Society. This is an Open Access article licensed under a Creative Commons Attribution 4.0 International License https://creativecommons.org/licenses/by/4.0/ unported [CC BY 4.0]. 


\section{Introduction}

Patients with end-stage renal disease (ESRD) are commonly treated with hemodialysis (HD), and intermittent peritoneal dialysis (PD) was used rarely before. The relative simplicity of the technique, its low cost, and the facility with which it could be performed by the patient at home all contributed to its popularity. In the first decade of the $21 \mathrm{st}$ century, it is estimated that more than 120,000 patients worldwide are being kept alive by $P D$, and this accounts for approximately $8 \%$ of the world's chronic dialysis population [1].

Continuous ambulatory peritoneal dialysis (CAPD) offers a number of advantages over HD as it can be done at home, allows better preservation of residual renal function, is associated with relatively stable blood chemistry and hydration status, does not require a vascular access and there is less risk of acquiring blood borne viral infections like hepatitis $B$ and C. CAPD is also associated with several complications - infectious and non-infectious. Noninfectious complications of CAPD are increasing in relative importance due to success in decreasing the rate of peritonitis. Catheter related problems are the major causes of technique failure and account for approximately $20 \%$ of change to HD [2,3].

Patients with ESRD in this region of the country are dependent on CAPD because of the lack of availability of hemodialysis services. Prevention, early recognition, and appropriate management of these complications are important because of associated patient morbidity and technique failure. There have been a number of other studies examining complications in general, with little emphasis on non-infectious complications of CAPD.

No studies have been conducted on this subject in thenorth eastern part of India

\section{Aims and Objectives}

Aims and objectives were to study the noninfectious complications in patients of ESRD on CAPD and to find out the impact of non-infectious complications in the survival of CAPD catheters.

\section{Materials and Methods}

Study type: prospective-observational study

Place of study: The study was carried out in the outpatient department and wards of Department of
MEDICINE and unit of NEPHROLOGY, Regional Institute of Medical Sciences, Imphal with clearance from the ethical committee, RIMS, Imphal.

Duration: The study was done during two calendar years from October 2012 to September 2014.

Study population: Patients of ESRD who are already on CAPD or newly diagnosed ESRD who have undergone CAPD catheter implantation were studied.

Sample size: This was a time bound study. A total of 71 patients who fulfilled the criteria were studied.

\section{Inclusion criteria}

01. ESRD patients already on CAPD

02. Patients with ESRD requiring new CAPD catheter implantation

03. Any age group

04. Both sexes

\section{Exclusion criteria}

01. Patients with infectious complications

02. Those who are not willing to participate in the study

ESRD: either of it present for $\geq 3$ months[4]

- albuminuria $>30 \mathrm{mg} /$ day

- urine sediment abnormalities ( e.g. hematuria, RBC casts etc)

- electrolyte and other abnormalities due to tubular disorders

- abnormalities detected by histology

- structural abnormalities detected by imagingwith

- GFR $<15 \mathrm{~mL} / \mathrm{min} / 1.73 \mathrm{~m} 2$

Statistical methods- All statistical calculations were performed with the SPSS 20 software. Comparisons between the groups were made with the paired $t$ test where appropriate. The Pearson correlation with two-tailed probability values was used to estimate the strength of association between variables. The level of statistical significance was set at $p$ value of $\leq 0.05$. All results were expressed as mean \pm SD.

\section{Results}

Out of the 71 patients, majority of the patients $(50.7 \%)$ were in the age group of 41 to 60 years. One child of 9 years was also included in the study 
(Table 1)

Table-1: Age distribution of patients of ESRD on CAPD $(n=71)$.

\begin{tabular}{|l|l|l|}
\hline \multicolumn{1}{|c|}{ Age in years } & \multicolumn{1}{c|}{ Frequency } & \multicolumn{1}{c|}{ Percent } \\
\hline$<20$ & 1 & 1.4 \\
\hline $21-40$ & 17 & 23.9 \\
\hline $41-60$ & 36 & 50.7 \\
\hline $61-80$ & 16 & 22.5 \\
\hline$>80$ & 1 & 1.4 \\
\hline Total & 71 & 100.0 \\
\hline
\end{tabular}

Gender classification shows male patients included in the study as $45(63.4 \%)$ and females $26(36.6 \%)$

Body mass index, haematological and biochemical parameters were assessed. Majority of patients had normal body mass index but low haemoglobin and albumin (Table 2)

Table-2: Haematological and biochemical parameters of patients of ESRD on CAPD $(n=71)$.

\begin{tabular}{|l|l|l|l|l|l|}
\hline & $\begin{array}{c}\text { Number of } \\
\text { patients }\end{array}$ & Minimum & Maximum & Mean & SD \\
\hline $\begin{array}{l}\text { Age on catheter } \\
\text { implantation. }\end{array}$ & 71 & 9 & 81 & 51.3 & 14.9 \\
\hline BMI & 71 & 11.48 & 30.09 & 21.7 & 2.7 \\
\hline Hemoglobin & 71 & 6 & 14 & 8.8 & 1.5 \\
\hline Blood Urea & 71 & 41 & 327 & 135.3 & 53.9 \\
\hline S.Creatinine & 71 & 4 & 20 & 9.2 & 3.7 \\
\hline S.Albumin & 71 & 2 & 4 & 3.1 & 0.5 \\
\hline Sodium & 71 & 88 & 145 & 132.4 & 8.8 \\
\hline Potassium & 71 & 3 & 7 & 4.1 & 0.8 \\
\hline Calcium & 71 & 5 & 9.8 & 9.3 & 1.9 \\
\hline Phosphorous & 71 & 3 & 12 & 4.9 & 1.5 \\
\hline S.Uric acid & 71 & 3.1 & 10.4 & 8.2 & 1.3 \\
\hline RBS & 71 & 62 & 290 & 140 & 56.8 \\
\hline
\end{tabular}

Hypokalemia (21.1\%) is the most common noninfectious complication found followed by the causes of catheter obstruction like wrapping of omentum around catheter (14.1\%) and catheter tip migration (8.5\%). (Table 3). About 11 patients had mild hyperkalemia and 4 patients had moderate hyperkalemia. None of them had severe hyperkalemia. Omental wrap was more in male patients ( 7 patients) compared to females (3 patients). Age wise distribution of omental wrap showed maximum in 41 to 60 age group (Table 4 ). Out of the study population $(n=71)$, the catheter tip migration was commonly found in the age group of 21to 40 years. (Table 5) 65 patients (92\%) remained on CAPD at the end of two years.
5 patients $(7 \%)$ were shifted to hemodialysis because of various reasons. One patient underwent renal transplantation. The functioning catheter was removed in two patients $(2.8 \%)$ because of recurrent peritonitis. The patients in whom catheters were removed had fungal peritonitis not responding to treatment. 23 patients (32.4\%) on CAPD expired at the end of two years. Most common cause of death in our study is inadequate dialysis contrary to other studies where the most common cause of death is CAD [4] (Figure 2)

Table-3: Frequency of non infectious complications in patients of ESRD on CAPD ( $n=71)$.

\begin{tabular}{|l|l|l|}
\hline \multicolumn{1}{|c|}{ Complication } & Number & Percentage \\
\hline Hypokalemia & 15 & 21.1 \\
\hline Omental wrap & 10 & 14.1 \\
\hline Catheter tip migration & 6 & 8.5 \\
\hline Hemoperitoneum & 2 & 2.8 \\
\hline Hydrothorax & 2 & 2.8 \\
\hline Exit site leak & 2 & 2.8 \\
\hline Abdominal wall edema & 1 & 1.4 \\
\hline Catheter block & 1 & 1.4 \\
\hline Total & 39 & 54.9 \\
\hline
\end{tabular}

Table-4: Age wise distribution of omental wrap in patients of ESRD on CAPD $(n=71)$.

\begin{tabular}{|l|l|l|l|}
\hline \multirow{3}{*}{$\begin{array}{c}\text { Age in } \\
\text { years }\end{array}$} & \multicolumn{2}{|c|}{ Omental wrap } & \multirow{2}{*}{ Total } \\
\cline { 2 - 3 } & Present & Absent & \\
\cline { 2 - 4 } & $\begin{array}{l}\text { Number } \\
\text { (percentage) }\end{array}$ & $\begin{array}{l}\text { Number } \\
\text { (percentage) }\end{array}$ & $\begin{array}{l}\text { Number } \\
\text { (percentage) }\end{array}$ \\
\hline$<20$ & $0(0)$ & $1(1.4)$ & $1(1.4)$ \\
\hline $21-40$ & $4(5.6)$ & $13(18.3)$ & $17(23.9)$ \\
\hline $41-60$ & $5(7.0)$ & $31(43.7)$ & $36(50.7)$ \\
\hline $61-80$ & $1(1.4)$ & $15(21.1)$ & $16(22.5)$ \\
\hline$>80$ & $0(0)$ & $1(1.4)$ & $1(1.4)$ \\
\hline Total & $10(14)$ & $61(86)$ & $71(100)$ \\
\hline
\end{tabular}

Table-5: Age wise distribution of catheter tip migration in patients of ESRD on CAPD $(n=71)$.

\begin{tabular}{|l|l|l|l|}
\hline \multirow{3}{*}{ Age in } & \multicolumn{2}{|c|}{ Catheter tip migration } & \multirow{2}{*}{ Total } \\
\cline { 2 - 3 } & Present & Absent & \\
\cline { 2 - 3 } & $\begin{array}{l}\text { Number } \\
\text { (percentage) }\end{array}$ & $\begin{array}{l}\text { Number } \\
\text { (percentage) }\end{array}$ & $\begin{array}{l}\text { Number } \\
\text { (percentage) }\end{array}$ \\
\hline$<20$ & $0(0)$ & $1(1.4)$ & $1(1.4)$ \\
\hline $21-40$ & $5(7.0)$ & $12(16.9)$ & $17(23.9)$ \\
\hline $41-60$ & $0(0)$ & $36(50.7)$ & $36(50.7)$ \\
\hline $61-80$ & $1(1.4)$ & $15(21.1)$ & $16(22.5)$ \\
\hline$>80$ & $0(0)$ & $1(1.4)$ & $1(1.4)$ \\
\hline Total & $6(8.4)$ & $65(91.5)$ & $71(100)$ \\
\hline
\end{tabular}




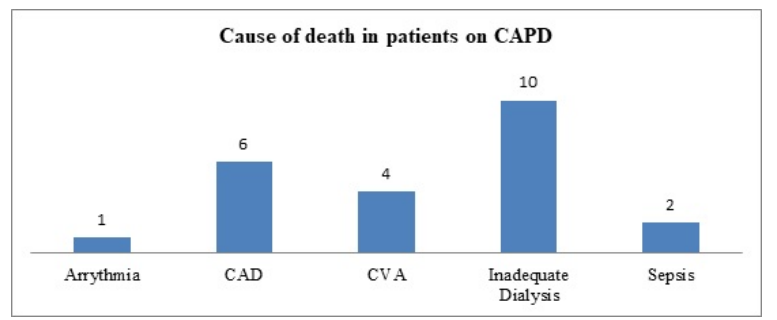

CAD- Coronary artery disease, CVA- Cerebro vascular accident

\section{Figure-2: Cause of death in patients of ESRD on CAPD $(n=71)$.}

\section{Discussion}

BMI in our study was $21.7 \pm 2.7 \mathrm{Kg} / \mathrm{m} 2$ The survival advantage associated with obesity was lower among CAPD patients compared to hemodialysis [5].

Hypokalemia: Hypokalemia was observed in 15 out of 71 patients in our study 11 patients had mild hypokalemia and 4 patients had moderate hypokalemia. Hypokalemia was not a major non infectious complications in our reference studies except in a study on Sudanese patients where hypokalemia was observed in 104 out of 296 patients studiedand it was the commonest noninfectious complication noticed [6]. It was reported that $10-15 \%$ of PD patients require potassium supplementation for hypokalemia [7]. Compared to patients on hemodialysis, CAPD patients have a normal or even higher intracellular potassium content. This phenomenon is probably related to the continuous glucose absorption from the dialysis solutions and the subsequent stimulation of intracellular uptake of potassium, mediated by insulin release [8].

Omental wrap: Omental entrapment around the tip of the catheter causing the catheter obstruction in our study was $23.94 \%$, which is lesser than that in studies reported (57\%-92\%) [9-11] except in a study done by Kavalakk at JP et al[12] accounting for $27.8 \%$ All the ten patients having this complication underwent an open surgery and partial omentectomy with catheter repositioning. None of the patients who underwent repair developed the same complication again during the study period.

Catheter tip migration: 2 out of the 6 patients had both omental wrap and catheter migration together. The incidence of catheter tip migration of our study was more compared to a study done by
Prakash J et al (4.4\%) [13], but was less compared to Marwa Miftah et al [14] who found catheter migration in $24.19 \%$ of the patients. All the patients who had catheter migration underwent catheter repositioning into the true pelvis through open surgery and CAPD could be continued.

Hemoperitoneum: Hemoperitoneum was observed in two patients in our study with an incidence rate of $5.1 \%$. The incidence of hemoperitoneum, even though not uncommon varies from 6 percent overall to as high as 57 percent in premenopausal women $[15,16]$. In a study done by Greenberg $A$ et al [15], 26 cases $(6 \%)$ of hemoperitoneum was observed out of a series of 424 patients.

Menstrual bleeding, use of anti-coagulants. Thrombo-cytopenia increased physical activity, catheter repositioning, femoral hematoma apart from peritonitis are the possible causes for hemoperitoneum.

Hydrothorax: Right sided hydrothorax was observed in $2(2.8 \%)$ cases. Incidence is approximately $2 \%$ in CAPD population [17].

Exit site leak and abdominal wall edema: Exit site leak was confirmed by the high glucose concentration of the leaked fluid.

The leak healed spontaneously on keeping the patient dry for 10 days and did not recur later on. The incidence of dialy sate leakage is more than $5 \%$ in CAPD patients [18].

Dialysate leak (exit site leak and abdominal wall edema) in our study contributed to $2.8 \%$ of the patients. The incidence of peritoneal leaks in CAPD is higher in obese patients than in other patients, because of the raised intra-abdominal pressure [19]. Our patient who had both exit site leak and abdominal wall edema had overweight with a BMI of $25.24 \mathrm{~kg} / \mathrm{m} 2$.

Catheter block: The block was presumed to be because of a fibrin clot as significant amount of fibrin strands were noted in the outflow fluid. So guidewire manipulation was carried out which relieved the obstruction.

Cause of death: Development of a hyperpermeable membrane, malnutrition and atherosclerosis (MIA) syndrome and disordered calcium-phosphate metabolism leading vascular calcification makes the serum of PD patients is more atherogenic than the serum of HD patients [20-23]. 
But in our study, the most common cause of death was inadequate dialysis (14.1\%). This is probably because of the poor socio-economic conditions in our country and unaffordability for adequate CAPD exchanges

\section{Conclusion}

Diabetes is the most common cause of ESRD. Most common non-infectious complication was a metabolic cause hypokalemia found in 15 patients $(21.1 \%)$ as compared to other studies where catheter related problems accounted for the commoner causes of complications. Though the study population with hypokalemia were asymptomatic, it can attribute to morbidity and progression to severe hyperkalemis in untreated patients will lead to tachyarrhythmias resulting in sudden cardiac death. The majority of noninfectious complications in these patients were treatable and did not interfere with the catheter survival. Non-infectious complications of CAPD can be prevented by good patient education on hygiene and handling errors, periodic retraining of patients and caregivers.

Addressing the complications of CAPD timely and efficient management of these problems is the cornerstone in the CAPD technique survival. What does this study add to the existing knowledge? Hypokalemia is an important and a frequent metabolic complication which should be watched for, Pain during the inflow or outflow of dialysate should not be overlooked as peritonitis in all the cases as the catheter related complications present with similar complaints.

\section{Reference}

01. Moeller S, Gioberge S, Brown G, et al. ESRD patients in 2001- global overview of patients, treatment modalities and development trends. Nephrol Dial Transplant. 2002 Dec;17(12)20716.

DOI: $10.1093 / n d t / 17.12 .2071$ [Crossref]

02. Schaubel DE, Blake PG, Fenton SS. Trends in CAPD technique failure- Canada, 1981-1997. Perit Dial Int. 2001 Jul-Aug;21(4)365-71. [Crossref]

03. Mujais S, Story K. Peritoneal dialysis in the USevaluation of outcomes in contemporary coh orts. Kidney Int Suppl. 2006 Nov;(103)S21-6. [Crossref]
04. Chapter 1- Definition and classification of CKD. Kidney International Supplements. 2013;3;1962.

[Crossref]

05. Abbott KC, Glanton CW, Trespalacios FC, et al. Body mass index, dialysis modality, and survival- analysis of the United States Renal Data System Dialysis Morbidity and Mortality Wave II Study. Kidney Int. 2004 Feb;65(2)597605.

DOI: $10.1111 / \mathrm{j} .1523-1755.2004 .00385 . x$ [Crossref]

06. Mekki MO, Fedail HM, Ali EMA, Mohammed BA, Al-Sanousi $H$, Elamin $S$, et al. Non-infectious Complications of Peritoneal Dialysis among Sudanese Patients- Five Years Experience. Arab J Nephrol Transplant. 2011;4(1)27-30. [Crossref]

07. Oreopoulos DG, Khanna R, Williams P, Vas SI. Continuous ambulatory peritoneal dialysis 1981. Nephron. 1982;30(4)293-303.

[Crossref]

08. Musso CG. Potassium metabolism in patients with chronic kidney disease (CKD), Part Ipatients not on dialysis (stages 3-4). Int Urol Nephrol. 2004;36(3)465-8.

[Crossref]

09. Amerling R, Maele DV, Spivak $H$, et al. Laparos copic salvage of malfunctioning peritoneal catheters. Surg Endosc. 1997 Mar;11(3)249-52. [Crossref]

10. Lee M, Donovan JF. Laparoscopic omentectomy for salvage of peritoneal dialysis catheters. J Endourol. 2002 May;16(4)241-4.

[Crossref]

11. Kimmelstiel FM, Miller RE, Molinelli BM, et al. La paroscopic management of peritoneal dialysis ca theters. Surg Gynecol Obstet. 1993;176(6)56570. [Crossref]

12. Kavalakkat JP, Kumar S, Aswathaman K, Kekre NS. Continuous ambulatory peritoneal dialysis catheter placement- Is omentectomy necessary?. Urol Ann. 2010;2(3)107-9.

[Crossref]

13. Prakash J, Sharath Chandra Singh LK, Shreenivas S, Ghosh B, Singh TB. Non infectious complications of continuous ambulatory peritoneal dialysis and their impact on technique survival. Indian J Nephrol. 2011;21(2)112-15. [Crossref] 
14. Marwa M, Mohammed A, Aicha B, Adil K, Ali I, Yassine N, Loubna B. Mechanical Complications of Peritoneal Dialysis. Open J Nephrol. 2014;4;103-9.

[Crossref]

15. Greenberg A, Bernardini J, Piraino BM, Johnston JR, Perlmutter JA. Hemoperitoneum complicating chronic peritoneal dialysis- singlecenter experience and literature review. Am J Kidney Dis. $1992 ; 19 ; 252-256$.

[Crossref]

16. Harnett JD, Gill D, Corbett L, et al. Recurrent hemoperitoneum in women receiving continuous ambulatory peritoneal dialysis. Ann Intern Med. 1987 Sep;107(3)341-3.

[Crossref]

17. Marel $M$, Zrůstová $M$, Stasný $B$, et al. The incidence of pleural effusion in a well-defined region. Epidemiologic study in central Bohemia. Chest.

1993 Nov;104(5)1486-9 [Crossref]

18. Leblanc M, Ouimet D, Pichette V. Dialysate leaks in peritoneal dialysis. Semin Dial. 2001 JanFeb; 14 (1)50-4.

[Crossref]
19. Schmekal B. Peritoneal dialysis in patients with high body-mass index. Wien Klin Wochenschr. 2005;117(Suppl 6)40-5.

DOI: $\quad 10.1007 / \mathrm{s} 00508-005-0495-8 \quad$ [Crossref]

20. Bergström J, Lindholm B. Malnutrition, cardiac disease, and mortality- an integrated point of view. Am J Kidney Dis. 1998 Nov;32(5)834-41. [Crossref]

21. Stenvinkel $P$, Heimbürger $O$, Paultre $F$, et al. Strong association between malnutrition, inflammation, and atherosclerosis in chronic renal failure. Kidney Int. 1999 May;55(5)1899911.

DOI: $10.1046 /$ j.1523-1755.1999.00422.x [Crossref]

22. Guérin AP, London GM, Marchais SJ, et al. Arterial stiffening and vascular calcifications in end-stage renal disease. Nephrol Dial Transplant. $2000 \mathrm{Jul} ; 15(7) 1014-21$.

DOI: $10.1093 / \mathrm{ndt} / 15.7 .1014$ [Crossref]

23. Milionis $\mathrm{HJ}$, Elisaff MS, Karabina SAP, Bairaktari E, Tselepis AD, Siamopoulos KC. Plasma and Lp(a)-associated PAF-acetylhydrolase activity in uremic patients undergoing different dialysis procedures. Kidney Int. 56;2276-2281;1999.

[Crossref] 